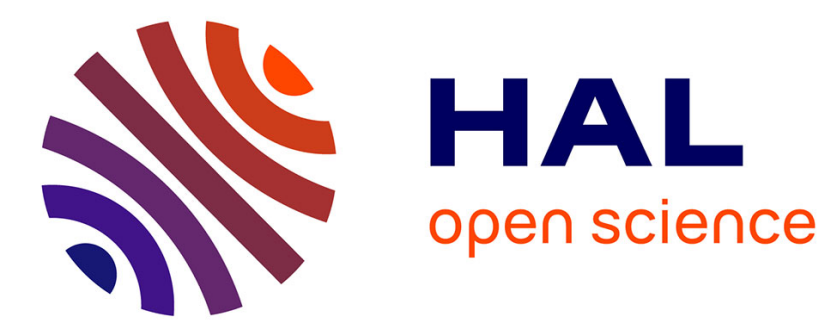

\title{
Peptide binding to ochratoxin A mycotoxin: a new approach in conception of biosensors.
}

Ingrid Bazin, Nicolas Andreotti, Aziza Ibn Hadj Hassine, Michel de Waard, Jean-Marc Sabatier, Catherine Gonzalez

\section{- To cite this version:}

Ingrid Bazin, Nicolas Andreotti, Aziza Ibn Hadj Hassine, Michel de Waard, Jean-Marc Sabatier, et al.. Peptide binding to ochratoxin A mycotoxin: a new approach in conception of biosensors.. Biosensors and Bioelectronics, 2013, 40 (1), pp.240-6. 10.1016/j.bios.2012.07.031 . inserm-00842794

\section{HAL Id: inserm-00842794 https://www.hal.inserm.fr/inserm-00842794}

Submitted on 9 Jul 2013

HAL is a multi-disciplinary open access archive for the deposit and dissemination of scientific research documents, whether they are published or not. The documents may come from teaching and research institutions in France or abroad, or from public or private research centers.
L'archive ouverte pluridisciplinaire HAL, est destinée au dépôt et à la diffusion de documents scientifiques de niveau recherche, publiés ou non, émanant des établissements d'enseignement et de recherche français ou étrangers, des laboratoires publics ou privés. 
Peptide binding to ochratoxin A mycotoxin: a new approach in conception of biosensors.

I. Bazin ${ }^{a^{*}}$, N. Andreotti ${ }^{\text {b }}$ A. Ibn Hadj Hassine ${ }^{\mathrm{a}}$, M. De Waard ${ }^{\mathrm{c}}$, J.M. Sabatier ${ }^{\mathrm{b}}$, C. Gonzalez $^{\mathrm{a}}$

${ }^{\text {a}}$ Ecole des Mines d'Ales, 6 avenue de Claviers 30319 Ales cedex.

${ }^{\mathrm{b}}$ INSERM UMR1097, Aix-Marseille Université, Parc scientifique de Luminy, Marseille, France.

'INSERM U836, Grenoble Institut des Neurosciences, Bâtiment Edmond Safra, 38042 Grenoble Cedex 09, France.

*Corresponding author: ingrid.bazin@mines-ales.fr

\section{Abstract}

Ochratoxin A (OTA) is a widespread and abundant natural carcinogenic mycotoxin produced by several species of Aspergillus and Penicillium fungi. Due to the ubiquitous presence of these fungi in food and potential risk for human health, a rapid and sensitive in vitro detection assay is required. Analytical methods for OTA detection/identification are generally based on liquid-liquid extraction, clean-up using an immunoaffinity column (IAC), and identification by reversed-phase high pressure liquid chromatography with fluorescence detection (HPLCFLD). However, IACs are costly and have a short lifespan. Therefore, an interesting approach would appear to be the design and chemical synthesis of a mimotope peptide simulating mycotoxin-specific antibodies. We have developed a promising alternative method that is based on the use of peptides which are able to bind to specific chemical functions and/or molecular structures. Accordingly, a number of peptides (derived from the structures of major redox proteins) were selected and produced by chemical solid phase syntheses. The ability of such peptides to bind to ochratoxin A was evaluated by HPLC. The peptide NF04 (structurally derived from an oxidoreductase enzyme), which was found to be the sole potently reactive compound among tested molecules, was further evaluated in a peptide-based enzyme-linked immunosorbent assay (peptide-based ELISA), thus confirming its specific interaction with ochratoxin A.

Keywords: peptide binding, peptide-based assay, ochratoxin A, mycotoxin

\section{Introduction}


Ochratoxin A, also referred to as OTA, is a coumarinic mycotoxin produced by several fungi species from Aspergillus (e.g., A. ochraceus) and Penicillium (e.g., P. verrucosum) genera under different environmental conditions (Scott et al., 1997; Brera et al., 2008). It is a mycotoxin that has been identified as a contaminant in grains, cereals, beans, coffee, dried fruits and wine (Zimmerli et al., 1995, Varga et al., 2006; Blessa et al., 2006). OTA is known to have nephrotoxic, immunotoxic, teratogenic and carcinogenic effects (O'Brien et al., 2005, Pfohl-Leszkowicz et al., 2002, Smith et al., 1995). Wine contamination by OTA has been described and largely reviewed by several authors (Varga et al., 2006; Blessa et al., 2006). This beverage is widely consumed and represents a major source of daily OTA intake for the population (Jorgensen et al., 2005). Thus, regulatory limits for OTA exist in many countries, especially in Europe where maximum limits for OTA in wine, grape juices and grape beverages, have been fixed at $2 \mu \mathrm{g}^{-1}$ (European Union, 2005, 2010). Nowadays, the most widely used quality control process relies on an immunoaffinity column (IAC), followed by reversed-phase high pressure liquid chromatography using fluorescence detection (HPLCFLD) (Visconti et al., 1999, Aresta et al., 2006). Because this mycotoxin is largely represented in food, availability of rapid, reliable and sensitive analytical methods for the detection of OTA is required to protect consumers' health. Despite the fact that the IAC procedure is rather simple, sensitive and quite reproducible, IACs are unfortunately too costly, together with short shelf lives. In the last decade, several groups attempted to develop appropriate alternative assays to improve rapidity and sensitivity, combined with cost reduction. Such methods rely on immunoassays, test strips and biosensors. First, a competitive ELISA kit has been used widely in recent years for the detection of OTA. ELISAs for ochratoxin content analyses have been reported in barley (Morgan et al., 1983). The assay sensitivity for detection of OTA in barley samples was circa $5 \mu \mathrm{g} \mathrm{kg}^{-1}$ (Ramakrishna et al., 1990). Angelini et al., (2008) compared performance of four extraction procedures and three commercial ELISA kits for OTA in grapes. Sometimes, IAC are used to concentrate OTA. The advantage of using IAC after the extraction procedure was the excellent detection limit, which was between 0.06 and $0.0075 \mu \mathrm{g} \mathrm{1^{-1 }}$. This detection limit depends on the ELISA kit used. Second, the test strip, also called lateral flow device or immunochromatographic strip (ICS) test, is based on a membrane loaded with immobilized antibodies. They are of simple use and give faster results (2 to $15 \mathrm{~min}$ ). Test strips are semiquantitative with different visual limits of detection (LOD) in function of the nature of sample (Krska et al., 2009; Shim et al., 2009). Initially, the LOD was set at ca. $500 \mu \mathrm{g} \mathrm{l}^{-1}$ of OTA (Cho et al., 2005; Rusanova et al., 2009), whereas, nowadays, the cutoff level dropped down 
to $1 \mu \mathrm{g} 1^{-1}$, which corresponds to the lower limit tolerated by the Food and Drugs Administration. Third, with regard to biosensors, their characteristics depend on the nature of the bioreceptor and the physical transducer. Antibodies, which show high selectivity and affinity towards mycotoxins, have been widely used to set up a variety of immunosensors (e.g. electrochemical, impedimetric or conductimetric immunosensors) against mycotoxins like OTA (Pietro-Simon et al., 2008; Liu et al., 2009; Alacon et al., 2006; Radi et al., 2008 and 2009).

The well-known favorable molecular recognition characteristics of an antibody (in terms of affinity and selectivity) are counterbalanced by the unfavorable use of different matrix samples or experimental conditions of assay (e.g. denaturation of antibodies in organic solvents). To overcome these drawbacks, several strategies have been followed such as development of new synthetic systems that mimic the recognition properties of antibodies. Indeed, many efforts have been made to substitute OTA antibodies by DNA aptamers (CruzAguado et al., 2008a, 2008b), molecularly imprinted polymers (MIP) (Ali et al., 2010; Yu et al., 2010) and phage display libraries (Giraudi et al., 2007). The isolation of oligonucleotide sequences (DNA aptamers) and synthetic receptor(s) (MIP) that recognize this class of target molecules have some advantages compared to antibodies. They can be generated easily and are stable at different $\mathrm{pH}$ values and/or at high temperatures. Among these approaches, based on synthetic systems, none of them reach affinity for OTA that is compatible with the detection limits fixed in wine by the European Commission $\left(2.0 \mu \mathrm{g}^{-1}\right)$ or the rest of the world $\left(1.0 \mu \mathrm{g} \mathrm{l}^{-1}\right)$. The first hexapeptide selected using phage display libraries exhibits an affinity of ca. $3.4 \times 10^{4} \mathrm{M}^{-1}$ towards OTA (Giraudi et al., 2007). Although moderate, such a peptide affinity can be potentially increased by some structure-activity relationship studies. Peptide-based detection assays in general are commercially available and most frequently used in the biomedical field rather than environmental sciences which is of concern in this study. For examples, peptides are used in various fields, from diagnosis of HIV infection (Alcaro et al., 2003; Ravanshad et al., 2006, Gerasimov 2010) to detection of potential sensitizing compounds (Gerberik et al., 2004).

Apart from the previously described techniques used for OTA quantification, we describe in this work for the first time a novel approach based on the identification of new peptides (not based on phage display analyses) which exhibit significant affinities towards OTA. HPLC was used as an analytical method to select the most potent peptide interacting with OTA in a binding assay. Identification of such a peptide is important and allowed us to analyze some 
red wine samples that were previously supplemented with OTA in a peptide-based enzymelinked immunosorbent assay (peptide-based ELISA).

2. Material and methods

\subsection{Materials}

$\mathrm{N}^{\alpha}$-fluorenyl-9-methyloxycarbonyl (Fmoc)-L-amino acids, Fmoc-amide rink resin, and reagents used for peptide synthesis were obtained from Iris Biotech (Germany). Solvents were analytical grade products from Carlo-Erba (France).

\subsection{Chemicals}

OTA was obtained from Sigma-Aldrich (France). A solution was prepared in methanol at 1 $\mathrm{mg} \mathrm{ml}^{-1}$. PEG 8000 (Polyethylene Glycol) and PVPP were obtained from Promega (France). Luminol was obtained from Pierce (France).

\subsection{Solid-Phase Peptide Synthesis}

The peptides (NF01, NF02, NF03, NF04, Chim1, pep01 and pep02) were produced by chemical synthesis using a peptide synthesizer (Model 433A, Applied Biosystems Inc.). The amino acid sequence of the most reactive peptide, i.e. NFO4, is provided in Fig. 2B. All peptide sequences are described in European patent $\mathrm{n}^{\circ} 12305269.8$ (deposited by Tournoux Biotech on March $5^{\text {th }}$ 2012). Peptide chains were assembled stepwise on $0.25 \mathrm{mmol}$ of Fmocamide resin (1\% cross-linked; $0.65 \mathrm{mmol}$ of amino group/g) using $1 \mathrm{mmol}$ of $N^{\alpha}-(9-$ fluorenyl)methyloxycarbonyl (Fmoc) L-amino acid derivatives. Side chain-protecting groups for trifunctional residues were: trityl for cysteine, and asparagine; $t$-butyl for tyrosine, glutamate and aspartate; 2,2,4,6,7-pentamethyldihydrobenzofuran-5-sulfonyl for arginine; and $t$-butyloxycarbonyl for lysine. $N^{\alpha}$-amino groups were deprotected by successively treating with 18 and $20 \%$ (v/v) piperidine/N-methylpyrrolidone for 3 and $8 \mathrm{~min}$, respectively. After three washes with $\mathrm{N}$-methylpyrrolidone, the Fmoc-amino acid derivatives were coupled (20 min) as their hydroxybenzotriazole active esters in $\mathrm{N}$-methylpyrrolidone (4-fold excess). After peptides were assembled, and removal of N-terminal Fmoc groups, the peptide resins (ca. 1.5 g) were treated under stirring for $2.5 \mathrm{~h}$ at $25^{\circ} \mathrm{C}$ with mixtures of trifluoroacetic acid/ $\mathrm{H}_{2} \mathrm{O} /$ thioanisole/ethanedithiol $(73: 11: 11: 5, \mathrm{v} / \mathrm{v})$ in the presence of crystalline phenol (2.1 $\mathrm{g}$ ) in final volumes of $30 \mathrm{ml}$ per gram of peptide resins. The peptide mixtures were filtered, precipitated and washed twice with cold diethyloxide. The crude peptides were pelleted by centrifugation $(3,200 \times \mathrm{g} ; 10 \mathrm{~min})$. They were then dissolved in $\mathrm{H}_{2} \mathrm{O}$ and freeze dried. The 
crude peptides were purified to homogeneity by reversed-phase high pressure liquid chromatography (HPLC) $\left(\mathrm{C}_{18}\right.$ Aquapore ODS, $20 \mu \mathrm{m}, 250 \times 10 \mathrm{~mm}$; PerkinElmer Life Sciences) by means of a 60 -min linear gradient of $0.08 \%(\mathrm{v} / \mathrm{v})$ trifluoroacetic acid $/ \mathrm{H}_{2} \mathrm{O}$ (buffer A) with 0 to $40 \%$ of $0.1 \%(\mathrm{v} / \mathrm{v})$ trifluoroacetic acid/acetonitrile (buffer B), at a flow rate of $4 \mathrm{ml} / \mathrm{min}(\lambda=230 \mathrm{~nm})$. The purity and identity of each peptide were assessed by: (i) analytical $\mathrm{C}_{18}$ reversed-phase HPLC $\left(\mathrm{C}_{18}\right.$ Lichrospher $5 \mu \mathrm{m}, 4 \times 200 \mathrm{~mm}$; Merck) using a 60 min linear gradient of buffer A with $0-60 \%$ of buffer $\mathrm{B}$, at a flow rate of $1 \mathrm{ml} / \mathrm{min}$; and (ii) molecular mass determination by matrix-assisted laser desorption ionization-time of flight (MALDI-TOF) spectrometry (Voyager DE-RP, Perceptive Biosystems Inc.).

\subsection{HPLC-based peptide binding assays}

Eighty microlitres of a peptide (NF01, NF02, NF03, NF04, Chim1, pep01 or pep02) at a concentration of $1.25 \mathrm{mM}$ in $0.1 \mathrm{M}$ Tris- $\mathrm{HCl}$ buffer, $\mathrm{pH} 8.3$, were tested with $10 \mu \mathrm{l}$ of OTA solution at $0.1 \mathrm{M}$ in acetonitrile, supplemented with $70 \mu \mathrm{l}$ of $0.1 \mathrm{M}$ Tris- $\mathrm{HCl}$ buffer (pH 8.3) and $40 \mu \mathrm{l}$ acetonitrile. The mixture of peptide and OTA was incubated for $4 \mathrm{~h}$ in the dark, at a temperature of $30^{\circ} \mathrm{C}$. The reaction medium $(200 \mu \mathrm{l})$ was then analyzed by $\mathrm{C}_{18}$ reversed-phase HPLC $\left(\mathrm{C}_{18}\right.$ Aquapore ODS, $20 \mu \mathrm{m}, 250 \times 10 \mathrm{~mm}$; PerkinElmer Life Sciences) by means of a 40-min linear gradient of $0.08 \%$ (v/v) trifluoroacetic acid/ $\mathrm{H}_{2} \mathrm{O}$ (buffer A) with 0 to $60 \%$ of $0.1 \%(\mathrm{v} / \mathrm{v})$ trifluoroacetic acid/acetonitrile (buffer B), at a flow rate of $1 \mathrm{ml} / \mathrm{min}(\lambda=230 \mathrm{~nm})$. Peptide reactivity with OTA was finally assessed by comparing the peak areas corresponding to free peptide (unreactive peptide) between the test sample of peptide/OTA, and a reference sample of peptide alone (without OTA). It is worth mentioning that results obtained with the reference samples (peptides alone) are similar to those obtained with peptides incubated with irrelevant, unreactive products (data not shown). The identity of free peptides and peptide/OTA complexes was verified by MALDI-TOF mass spectrometry. Binding assays were performed in triplicate.

\subsection{Peptide-based competitive enzyme-linked immunosorbent assay (peptide-based} competitive ELISA)

Polystyrene white microtiter plate wells (Maxisorb LumiNunc, Thermoscientific, USA), coated with the synthetic peptide NFO4 at an optimized concentration of $5 \mu \mathrm{g} / 100 \mu \mathrm{l}$ in carbonate buffer ( $15 \mathrm{mM} \mathrm{Na}_{2} \mathrm{CO}_{3}, 35 \mathrm{mM} \mathrm{NaHCO}_{3}, 0.2 \mathrm{~g} / \mathrm{L} \mathrm{NaN}_{3}, \mathrm{pH}$ 9.6) were incubated at $37^{\circ} \mathrm{C}$ for $3 \mathrm{~h}$. Non-specific binding sites of the peptide-coated wells were blocked with $5 \%$ 
nonfat dry milk in PBS containing 0.1\% Triton X-100 (milk buffer) at room temperature (RT) for $3 \mathrm{~h}$ before performing the test. Fifty $\mu \mathrm{l}$ of OTA-HRP (horseradish peroxidase) were added in each well combined with $50 \mu$ l of phosphate buffer saline or red wine sample supplemented with unlabeled OTA. The reaction was left for $30 \mathrm{~min}$ at RT. After washing unbound OTA, $40 \mu \mathrm{l}$ of luminol (Pierce, France) substrate was added in each well. After 5 min of enzymatic reaction, light emission signals $(\lambda \max =425 \mathrm{~nm})$ were analyzed using an automated microplate luminescence reader (Berthold, France). Light intensity was expressed in Relative Luminescent Unit (RLU). The result obtained is inversely proportional to the concentration of unlabeled OTA. During each test, nonspecific binding (negative control) was determined by using an incubation mixture (OTA-HRP) in which the peptide NFO4 was replaced by $100 \mu \mathrm{L}$ of carbonate buffer. All the samples were tested in triplicate and the mean of the peak light emission was taken as the final light signal value.

\subsection{Calculation methods}

In order to evaluate the peptide-based competitive assay, a calibration curve was set up by using solutions containing well-defined concentrations of OTA. In that direct competitive peptide-based ELISA, results are expressed in B/Bo dose logarithmic function. B and Bo represent the enzyme-bound activity measured in the presence or absence of competitor, respectively. The standard curve was traced by plotting standard concentrations on $\mathrm{x}$-axis (logarithmic scale) and percentage of maximal binding (express in $\%$ of $\mathrm{B} / \mathrm{B}_{0}$ ) on $\mathrm{y}$-axis $(\mathrm{B} /$ $\mathrm{Bo}=\mathrm{f}(\log [\mathrm{OTA}]))$. The binding values are obtained by dividing the light intensity of each testing well B (the luminescence measured when OTA-HRP and unlabeled OTA are in competition with NFO4 peptide) by the light intensity of the positive control well $\mathrm{B}_{0}$ (maximum luminescence obtained with OTA-HRP). This method allows the comparison of results between assays performed on different plates or different days. While the absolute light emission may differ from plate to plate or day to day, the percentage of $\mathrm{B} / \mathrm{Bo}$ values should be reasonably consistent from one plate to the next. All measurements were made in triplicate. The minimum detectable concentration (MDC) was taken as the concentration of competitor (unlabeled OTA) inducing a significant decrease in Bo. The effect of complex matrix was established by testing a red wine sample.

\subsection{Specificity measurements}


The specificity of the peptide immunoassay described previously was controlled by testing its capacity to detect or not ochratoxin B (OTB), another mycotoxin structurally related to OTA. Results are expressed as percentage of cross-reactivity, defined as the ratio (\%) of the concentration of OTA and OTB compounds at 50\% B/Bo. Cross-reactivity measurement was carried out in triplicates.

\subsection{Preparation of matrix samples for peptide EIA: wine pretreatment}

In order to study matrix-associated effects, a study with red wine was carried out. A sample of $10 \mathrm{ml}$ of wine supplemented (or not) with OTA $\left(1.25\right.$ to $15 \mu \mathrm{g} \mathrm{l}^{-1}$ ) has been diluted with 10 $\mathrm{mL}$ of PEG8000 1\% - $\mathrm{NaHCO}_{3} 5 \%$ solution. This mixture has been incubated for $30 \mathrm{~min}$ at RT on a rocker. Afterwards, it was centrifuged at $8000 \mathrm{rpm}$ for $15 \mathrm{~min}$. The whole sample is filtered before analysis with the peptide-based enzyme-linked immunosorbent assay.

\section{Results and discussion}

\subsection{Rationale of the study}

The mycotoxin OTA from Aspergillus (e.g., A. ochraceus) and Penicillium (e.g., P. verrucosum) genera is a complex organic compound that contains several functional groups, including carbonyl (ester: $\mathrm{R}^{1} \mathrm{COOR}^{2}$, and amide: $\mathrm{R}^{1} \mathrm{CONHR}^{2} \mathrm{R}^{3}$ ) and phenol (i.e $\phi$-OH) moieties (Fig. 1A). We designed and chemically produce a number of peptides (European patent deposit $\mathrm{n}^{\circ} 12305269.8,2012$ ) derived from specific regions of redox proteins (e.g. oxidoreductase) and ABC transporters that potently react -in an HPLC-based binding assaywith more or less complex molecules containing such functional group(s), i.e carbonyl and/or phenol (Table 1a and b). The carbonyl group (i.e $\mathrm{C}=\mathrm{O}$ ) is shared by several types of organic compounds and comprises ketone, aldehyde, ester, amide, carboxylic acid, acid anhydride, enone and acyl halide. We evaluated whether or not these selected peptides would interact with OTA. As shown in Table 2, three peptides (NFO2, NFO3 and NFO4), with related molecular structures (up to $83 \%$ sequence identity) derived from human NADH-FMN oxidoreductase significantly interacted with the mycotoxin. The experimental molecular masses, as determined by MALDI-TOF mass spectrometry, were $(\mathrm{M}+\mathrm{H})^{+}: 1793.17 \mathrm{Da}$ (NFO2), 1722.15 Da (NFO3) and 1598.99 Da (NFO4), consistent with their calculated molecular structures. Among reactive peptides, NFO4 was the most potent compound, with $70 \%$ binding to OTA in our experimental conditions of binding assay. NFO4 amino acid sequence is provided in Fig. 1B. Fig. 2A shows binding assays with representative HPLC profiles of three reaction media corresponding to NF04 incubated for $4 \mathrm{~h}$ at $30^{\circ} \mathrm{C}$ with lactic 
acid as negative control (left panel), hydroquinone as positive control (center panel) and OTA (right panel). Interaction of NFO4 with hydroquinone or OTA is highlighted by the disappearance (hydroquinone) or decrease (OTA) of peak area corresponding to free-unbound NFO4. HPLC profiles showing binding of other peptides to OTA are also shown for comparison (Fig. 2B). For example, NFO1 and Chim1 showed binding inferior to $10 \%$, while NFO2 showed binding at $35 \%$.

Using NFO4, the threshold of OTA detection was found to be in the same concentration range as the one requested by the European commission regulation $\left(2 \mu \mathrm{g} \mathrm{l}^{-1} \mathrm{OTA}\right)$. Although the potency of OTA detection by NFO4 is actually moderate, one can anticipate that optimizing both NFO4 structure (in a structure-activity relationship study) and the experimental conditions of binding assay could improve sensitivity of peptide-based detection, and yield to the desired mycotoxin detection range in wine. Overall, experimental data obtained strongly suggest that, basically, a peptide-based detection assay of OTA might be a promising approach.

\subsection{Peptide-based competitive enzyme-linked immunosorbent assay}

Competitive ELISAs are most commonly used to measure various molecules including lipids, hormones, and small peptides if they are present in high enough concentrations. In this study, this type of assay is based on the competition between the analyte of interest, OTA, and an enzyme horseradish peroxidase-conjugated version of the same analyte (referred to as the tracer, OTA-HRP) for a limited number of specific peptide NFO4 binding sites (Fig. 3). The concentration of OTA-HRP is held constant in all wells while the concentration of OTA varies from well-to-well $\left(0 \mu \mathrm{g}^{-1}, 1.25 \mu \mathrm{g} \mathrm{l}^{-1}, 2 \mu \mathrm{g} \mathrm{l} \mathrm{l}^{-1}, 2.5 \mu \mathrm{g} \mathrm{l}^{-1}, 5 \mu \mathrm{g} \mathrm{l}^{-1}, 10 \mu \mathrm{g}{ }^{-1}\right.$ and 15 $\mu \mathrm{g}^{-1}$ ). As a result, the amount of tracer that can bind to the peptide NFO4 will be inversely proportional to the amount of analyte in the well - the presence of more analyte means less tracer will be able to bind to the specific peptide.

The standard curves obtained for peptide-based competitive ELISA in PBS are shown (Fig. 4A). The exponential curve fit for the standard OTA in PBS gives a clear graphical representation of how the competition proceeds. Inhibition starts at $1.25 \mu \mathrm{g} \mathrm{l^{-1 }}$ and reaches a maximum at $10 \mu \mathrm{g} \mathrm{l}^{-1}$. Inhibition is complete which is expected since the tracer is also OTAbased. Half-inhibition occurs at a value of $3.2 \mu \mathrm{g} \mathrm{1^{-1 }}$, which should grossly correspond to the $\mathrm{K}_{\mathrm{d}}$ value of NFO4 for OTA. We consider that with this test the LOD for OTA is at $1.25 \mu \mathrm{g}^{-1}$ and that differences in OTA concentration can be discriminated between 1.25 and $10 \mu \mathrm{g}^{-1}$. Cross-reactivity measurement of the peptide test was carried out using OTB (Fig. 4A). The 
OTB concentration inducing $50 \%$ of the maximum possible decrease of the light signal was $8.5 \mu \mathrm{g}^{-1}$, indicating that the affinity of NFO4 for OTB is circa 3 -fold lower than for OTA. In addition, free OTB was a worse competitor than OTA for decreasing OTA-HRP signal. Maximal decrease reached $69 \%$ instead of $100 \%$ for concentrations above $15 \mu \mathrm{g} \mathrm{l^{-1 }}$. At $10 \mu \mathrm{g}$ $1^{-1}$, OTA depleted the signal by $89 \%$, whereas OTB reduced it by $47 \%$ clearly indicating that OTA detection was better than OTB with this system. Next, we evaluated whether our system could detect OTA from red wine samples. The same range of OTA concentrations was added to red wine samples. The resulting competition curve was compared to that established with pure OTA or OTB in PBS (Fig. 4A). Wine OTA could nicely be detected by the system, with a slight reduction in efficacy which can easily be explained by the enhanced number of non specific compounds co-present in wine samples. Half-inhibition occurred at $5.8 \mu \mathrm{g} \mathrm{l}^{-1}$ and as for OTA in PBS the inhibition was complete. The LOD for OTA in wine was $2 \mu \mathrm{g} \mathrm{l}^{-1}$ (Fig. $4 \mathrm{~B})$, which is only slightly higher than OTA in PBS. These results suggested that the NFO4 peptide can be used for detection of OTA in red wine matrices.

\section{Conclusions}

The European Union (EU) has defined regulatory limits for OTA, i.e., $10 \mu \mathrm{g} \mathrm{l}^{-1}$ in dried vine fruits and instant coffee, $5 \mu \mathrm{g} \mathrm{l}^{-1}$ in cereals and roasted coffee and $2 \mu \mathrm{g} \mathrm{l}^{-1}$ in wine. Here we present a new strategy for detection of this important mycotoxin in various matrices like red wine. We have selected small peptides (12 amino acids) allowing specific recognition of OTA. The peptide named NFO4 was selected in HPLC for its higher affinity for OTA. We have validated this result by a peptide-based competitive ELISA in phosphatase buffer saline and in red wine samples. The peptide-based competitive ELISA showed that NFO4 can discriminate a contamination of $2 \mu \mathrm{g} \mathrm{l}^{-1}$ of OTA in red wine (without preconcentration of the sample on immunoaffinity column). This preliminary study highlights the possibility of using small peptides in biosensor systems (e.g. by electrochemical detection). Modifications of NFO4 peptide sequence may be required in order to further decrease the observed crossreactivity with OTB which is potentially related to the phenol moiety of OTB. Such a structure-activity relationship study may increase the LOD to the lower value of $1 \mu \mathrm{g} \mathrm{l}^{-1}$ which is the world limit for OTA in red wineIn any case, these preliminary data are quite encouraging and strongly suggest that further work on NFO4 will allow the development of a more sensitive system, either by peptide modification or by OTA preconcentration by an affinity column. 


\section{References}

Alarcon, S.H., Palleschi, G., Compagnone, D., Pascale, M., Visconti, A., Barna-Vetró, I., 2006. Talanta. 69, 1031-1037.

Alcaro, MC, Peroni, E, Rovero, P, Papini, A.M., 2003. Curr Protein Pept Sci. 4, 285-90.

Ali, W.H., Derrien, D., Alix, F., Pérollier, C., Lépine, O., Bayoudh, S., Chapuis-Hugon, F., Pichon, V., 2010. J. Chromatogr. A. 1217, 6668-6673.

Angelini, E., Bazzo, I., Savino, M., Borgo, M., J Food Prot. 2008.71, 2488-96.

Aresta, A., Vatinno, R., Palmisano, F., Zambonin, C.G., 2006., J. Chromatogr. A 1115, 196201.

Belchik, S.M., Xun, L., 2011. Drug Metab Rev. 43, 307-16.

Birzele, B., Prange, A., Krämer, J., Food Addit Contam. 2000.17,1027-1035.

Blesa, J., Soriano, J.M., Molto, J.C., Manes, J., 2006. Crit. Rev. Food Sci. Nutr. 46, 473-478.

Brera, C., De Santis, B., Debegnach, F., Miraglia, M., Yolanda, P., 2008. Mycotoxins in FoodContaminants and Residue Analysis, Comprehensive Analytical Chemistry; Elsevier: Amsterdam, The Netherland, Volume 51, pp. 363-427.

Chen, X.M., Kobayashi, H., Sakai, M,. Hirata, H., Asai, T., Ohnishi ,T., Baldermann ,S., Watanabe, N., 2011. J Plant Physiol. 168, 88-95.

Cho, Y.J., Lee, D.H., Kim, D.O., Min, W.K., Bong, K.T., Lee, G.G., Seo, J.H., 2005. J. Agric. Food Chem. 53, 8447-8451

Cocchiara, J., Letizia, C.S., Lalko, J., Lapczynski, A., Api, A.M., 2005. Food Chem Toxicol. 43, 867-923.

Cruz-Aguado, J.A., Penner, G., 2008. Anal. Chem. 80, 8853-8855.

Cruz-Aguado, J.A., Penner, G., 2008. J. Agric. Food Chem. 56, 10456-10461.

European Commission Regulation N. 123/2005, European Union, Brussels.

European Commission Commission Regulation (EU) No. 105/2010. Off. J. Eur. Union. 2010. $35: 7-8$.

Franchini, A., Malagoli, D., Ottaviani, E., 2010. Mar Drugs. 16, 658-77.

Gerasimov, J.Y., Lai, R.Y., 2010. Chem Commun (Camb). 46, 395-7.

Gerberick,G. F., Vassallo, J.D., Bailey, R.E., Chaney, J.G., Morrall, S.W., Lepoittevin, J.P., 2004. Toxicological Sciences. 81, 332-343.

Giraudi, G., Anfossi, L., Baggiani, C., Giovannoli,,C., Tozzi, C., 2007. J. Chromatogr. A, $1175,174-180$.

Girschikofsky, M., Rosenberger, M., Belle, S., Brutschy, M., Waldvogel, SR., Hellmann, R., Sensors (Basel). 2012. 12, 2018-25.

Jorgensen, K., 2005. Food Addit. Contam. 22 (Suppl 1). 26-30.

Krska, R., Molinelli, A., 2009. Anal. Bioanal. Chem. 393, 67-71.

Liu, X.-P., Deng, Y.-J., Jin, X.-Y., Chen ,L.-G., Juang, J.-H., Shen ,G.-L., Yu, R.-Q., 2009. Anal. Biochem. 389, 63-68. 
Mateo R, Medina A, Mateo EM, Mateo F, Jiménez M. Int J Food Microbiol. 2007 Oct 20;119(1-2):79-83. Epub 2007 Jul 31. Review.

Morgan, M.R., McNerney, R., Chan, H.W., J Assoc of Anal Chem. 1983. 66, 1481-1484.

O’Brien, E., Dietrich, D.R. 2005. Crit. Rev. Toxicol. 35, 33-60.

Pohland, A.E., Nesheim, S., Friedman, L., 1992. Pure Appl. Chem. 64, 1029-1046.

Pfohl-Leszkowicz, A., Petkova-Bocharova,T., Chernozemsky, I.N., Castegnaro, M. 2002. Food Addit. Contam. 19, 282-302.

Prieto-Simón, B., Campàs, M., Marty, J.-L., Noguer, T. 2008. Biosens. Bioelectron. 23, 9951002.

Quartier, S., Garmyn, M., Becart, S., Goossens, A., 2006. Contact Dermatitis. 55, 257-67.

Radi, A.-E., Muñoz-Berbel, X., Lates, V., Marty, J.-L., 2008. Biosens. Bioelectron. 24, 18881892

Radi, A.-E., Muñoz-Berbel, X., Cortina-Puig, M., Marty, J.-L. 2009. Electrochim. Acta. 54, 2180-2184.

Ramakrishna, N., Lacey, J., Candlish, A.A., Smith, J.E., Goodbrand, I.A., J Assoc of Anal Chem. 1990. 73, 71-76

Ravanshad, M., Sabahi, F., Mahboudi, F., Kazemnejad, A., 2006. Saudi Med J. 27, 31-6.

Rusanova, T.Y., Beloglazova, N.V., Goryacheva, I.Y., Lobeau, M., van Peteghem, C., de Saeger, S. 2009. Anal. Chim. Acta. 653, 97-102.

Ryan, C.A., Gerberick, G.F., Cruse, L.W., Basketter, D.A., Lea, L., Blaikie, L., Dearman, R.J., Warbrick, E.V., and Kimber, I. 2000. Contact Dermatitis 43, 95-102.

Scott, P.M. 1997. Mycotoxins in Grain-Compounds Other than Aflatoxin; Miller, J.D., Trenholm, H.L.,Eds.; Eagan Press: Saint Paul, MN, USA,; p. 261.

Shen, X., Zhang, G., Zhang, D. 2012. Org Lett. 14, 1744-7.

Shim, W., Dzantiev, B.B., Eremin, S.A., Chung, D., 2009. J. Microbiol. Biotechnol.19, 8392.

Smith, J.E., Solomons, G., Lewis, C., Anderson, J.G., 1995. Nat. Toxins 3, 187-192

Ueno, Y., Kawamura, O., Sugiura, Y., Horiguchi, K., Nakajima, M,. Yamamoto, K., Sato, S., IARC Sci Publ. 1991. 115, 71-75.

Varga, J., Kozakiewicz, Z., 2006. Trends Food Sci. Technol. 17. 72-81.

Visconti, A.; Pascale, M.; Centonze, G. 1999. J. Chromatogr. A. 864, 89-101.

Yu, J.C.C., Lai, E. P.C., 2010. Toxins 2, 1536-1553.

Zimmerli, B., Dick, R., 1995. J. Chromatogr. B 666, 85-99.

Figure captions

Figure 1: (A) Chemical structure of Ochratoxin A mycotoxin. (B) Amino acid sequence of NFO4. Single letter code. 
374 Figure 2 : HPLC-based peptide-based binding assays. (A) Representative HPLC profiles of 375 three reaction media corresponding to NF04 incubation with lactic acid as negative control 376 (left panel), hydroquinone as positive control (center panel) and OTA (right panel). Lactic 377 acid is not detected on the HPLC profile because of lack of absorption at $230 \mathrm{~nm}$. Complexes 378 between NF04 and compounds are not detected on HPLC profiles. (B) Representative HPLC 379 profiles of three peptides incubated with OTA: NFO1 (left), NFO2 (middle), and Chim1 380 (right). Peak peptide depletions according to control without OTA (not shown) are 7\% 381 (NFO1), 35\% (NFO2) and 10\% (Chim1).

382

383 Figure 3. Principle of competitive immunoassay with conjugated OTA. (A) The plate is 384 coated with the peptide NFO4. (B) The peptide is then placed in contact with the sample. If the sample contains the specific OTA, the toxin links to the specific peptide and the detection element conjugated with the toxin (usually HRP). (C) The amount of HRP-conjugated toxin that can be fixed is inversely correlated with the amounts of toxin present in the sample. (D) The non-fixed compounds are rinsed away before adding a developing product.

Figure 4. (A) Peptide-based competitive ELISA calibration curve. The $x$-axis represents the calibrator concentration of mycotoxin (OTA or OTB). B and Bo represent the bound enzyme activity measured in the presence or absence of competitor, respectively. Data are average \pm standard deviation, and were fitted by decreasing exponential functions $y=y_{0}+a \cdot e^{-b x} . Y_{0}$ values were $<10$ for OTA (wine and PBS) and >30 for OTB. (B) Peptide-based competitive ELISA with OTA in wine. The negative control is the luminescence emitted with OTA-HRP without NFO4 peptide. Data are the mean of $n=3 \pm$ standard deviation. 
Table 1a: HPLC-based peptide binding assays. Percentages of peak area depletion are noted. ' 100 ' corresponds to $100 \%$ binding of peptide to indicated chemical compound. ' 0 ' corresponds to a lack of interaction between peptide and organic compound.

\begin{tabular}{|l|c|c|c|c|c|}
\hline $\begin{array}{l}\text { Peptides/chemical } \\
\text { compounds }\end{array}$ & NFO1 & NFO2 & NFO3 & NFO4 & Chim1 \\
\hline Hydroquinone & 100 & 90 & 100 & 100 & 80 \\
\hline Phtalic anhydride & 95 & 100 & 100 & 100 & 85 \\
\hline Diphenylcyclopropenone & 0 & 98 & 100 & 99 & 85 \\
\hline Cinnamic aldehyde & 55 & 35 & 100 & 100 & 90 \\
\hline Phenylacetaldehyde & 80 & 20 & 35 & 100 & 55 \\
\hline Lactic acid & 0 & 0 & 0 & 0 & 0 \\
\hline Okadaic acid & 0 & 0 & 0 & 0 & 0 \\
\hline Naphtalene & 0 & 0 & 0 & 0 & 0 \\
\hline
\end{tabular}


Table 1b: Chemical structures of organic compounds studied in HPLC-based peptide binding assays.

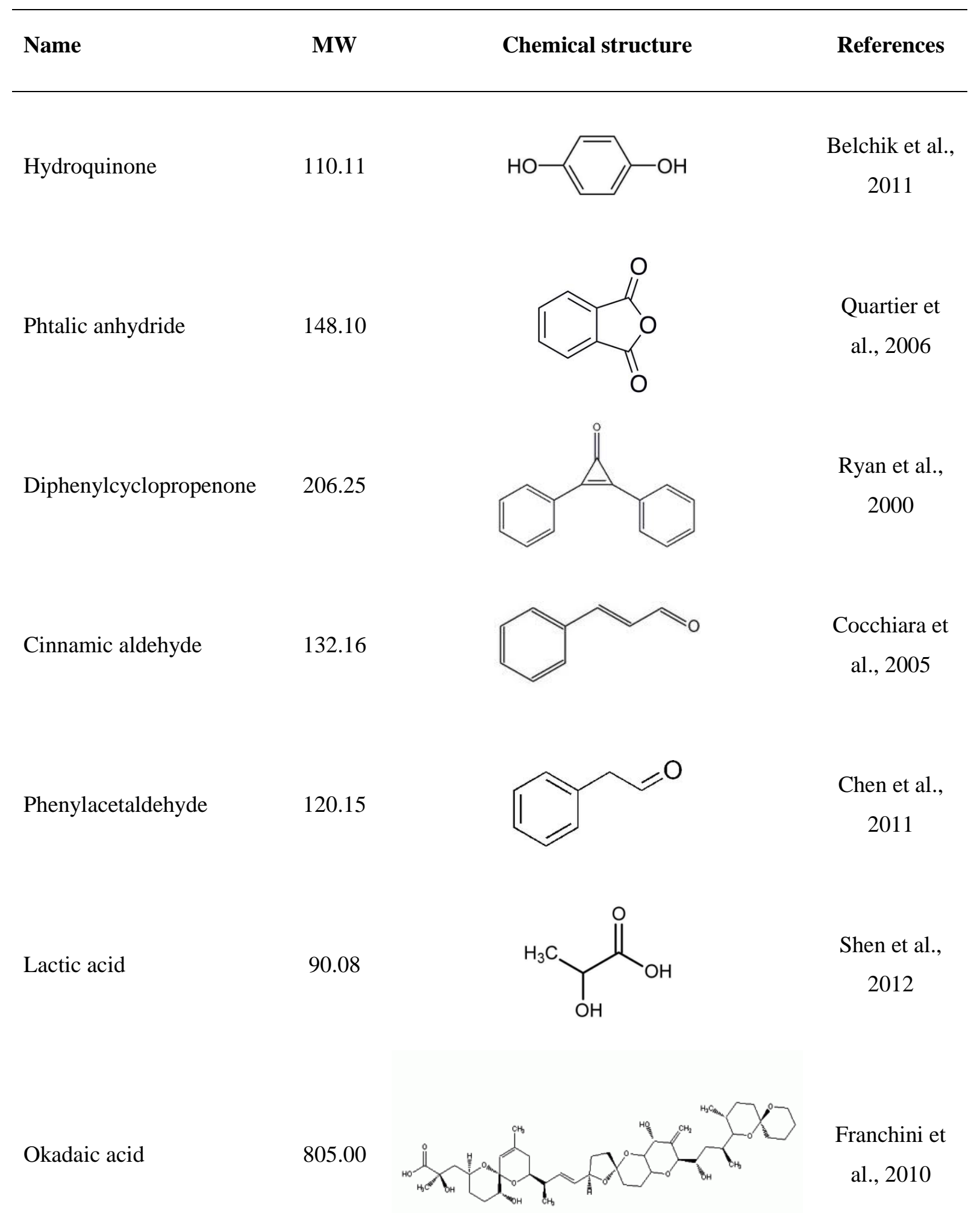


Table 2: Peptide binding assay. Percentages of peak area depletion are noted. ' 100 ' corresponds to $100 \%$ binding of peptide to organic compound. ' 0 ' corresponds to a lack of interaction.

\begin{tabular}{lccccc}
\hline $\begin{array}{l}\text { Peptides/chemical } \\
\text { compounds }\end{array}$ & NFO1 & NFO2 & NFO3 & NFO4 & Chim1 \\
\hline OTA & 7 & 35 & 40 & 70 & 10 \\
Hydroquinone** & 100 & 90 & 100 & 100 & 80 \\
Lactic acid* & 0 & 5 & 4 & 7 & 1 \\
\hline
\end{tabular}

** Positive control ; * Negative control 
Figure 1

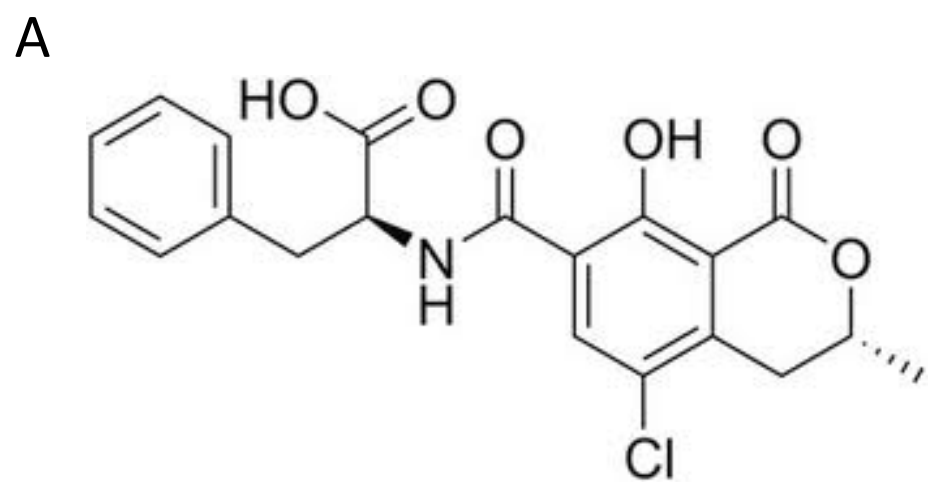

B

NFO4 primary structure

$\underset{1}{\text { VYMNR }} \underset{5}{\mathrm{KYYKC}} \underset{10}{\mathrm{C} K-\mathrm{NH}_{2}}$ 


\section{Figure 2}

A
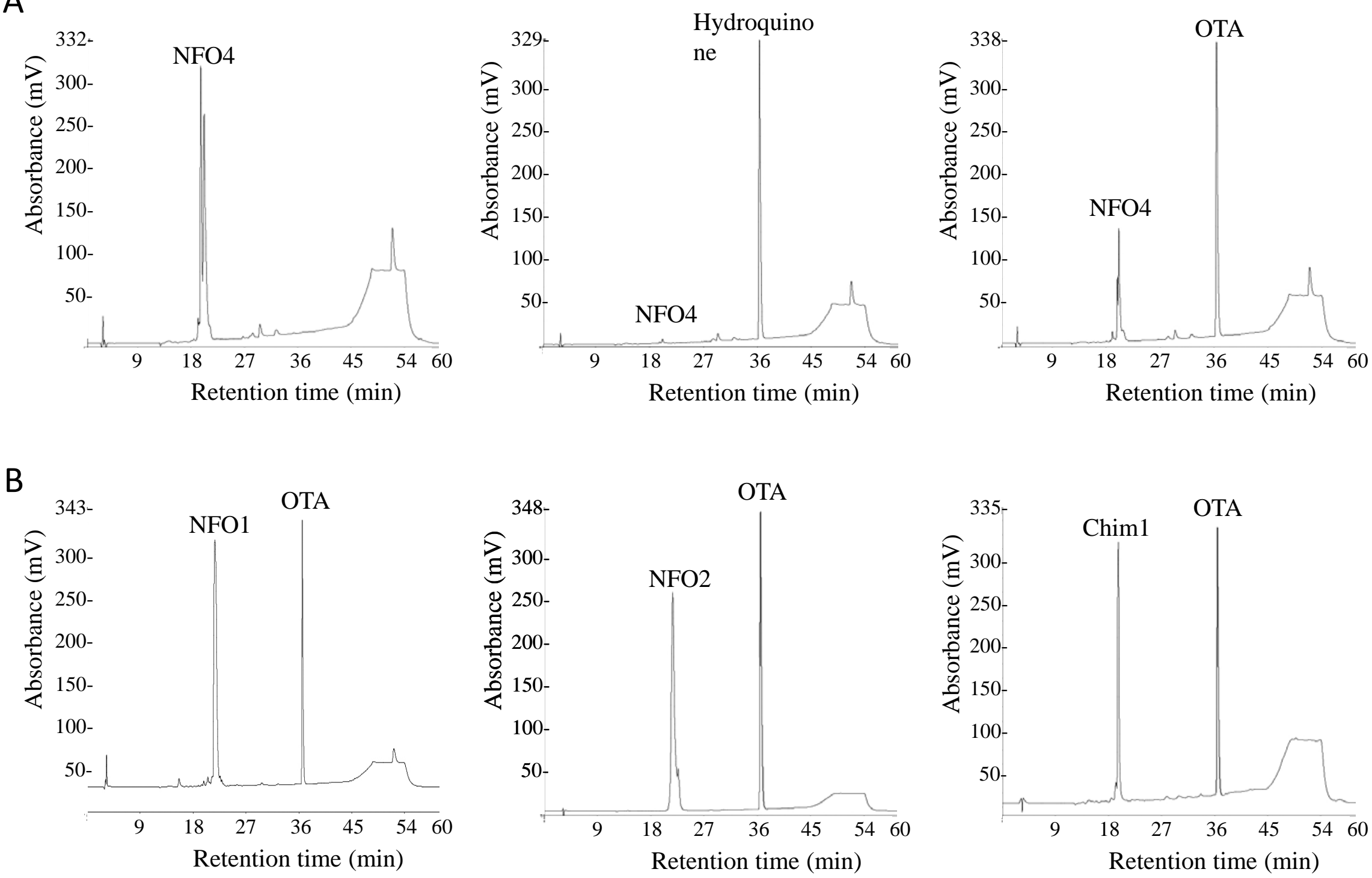
Figure 3

A

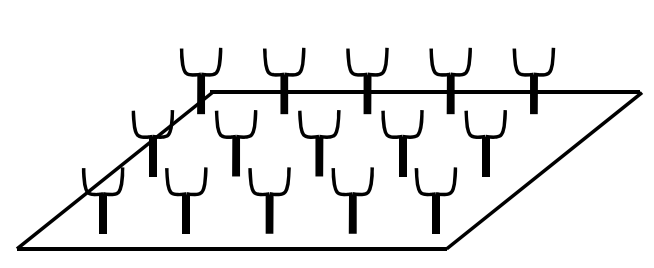

C

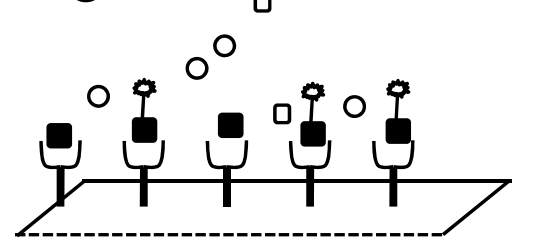

B

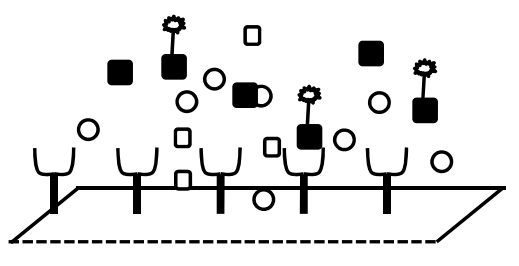

D

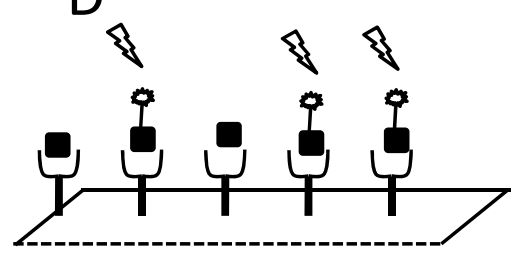

ب Peptide NFO4 anti-OTA

- OTA

○O Other compounds (interferences)

i OTA-HRP

\& Developper (substrate) 


\section{Figure 4}

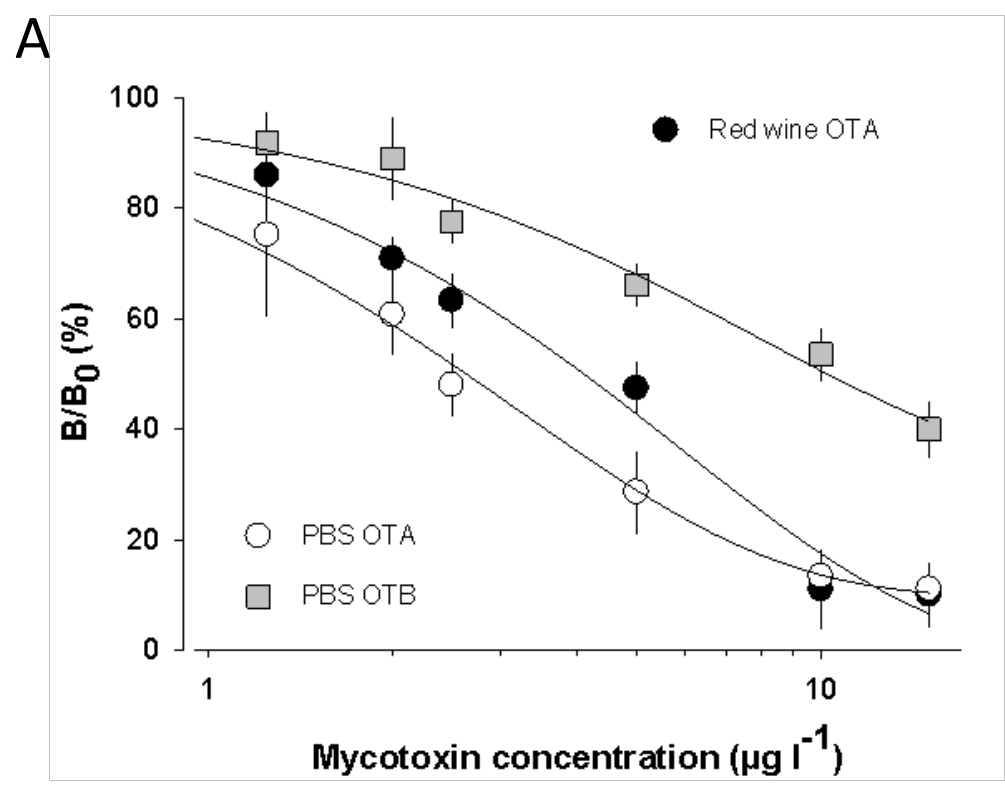

B

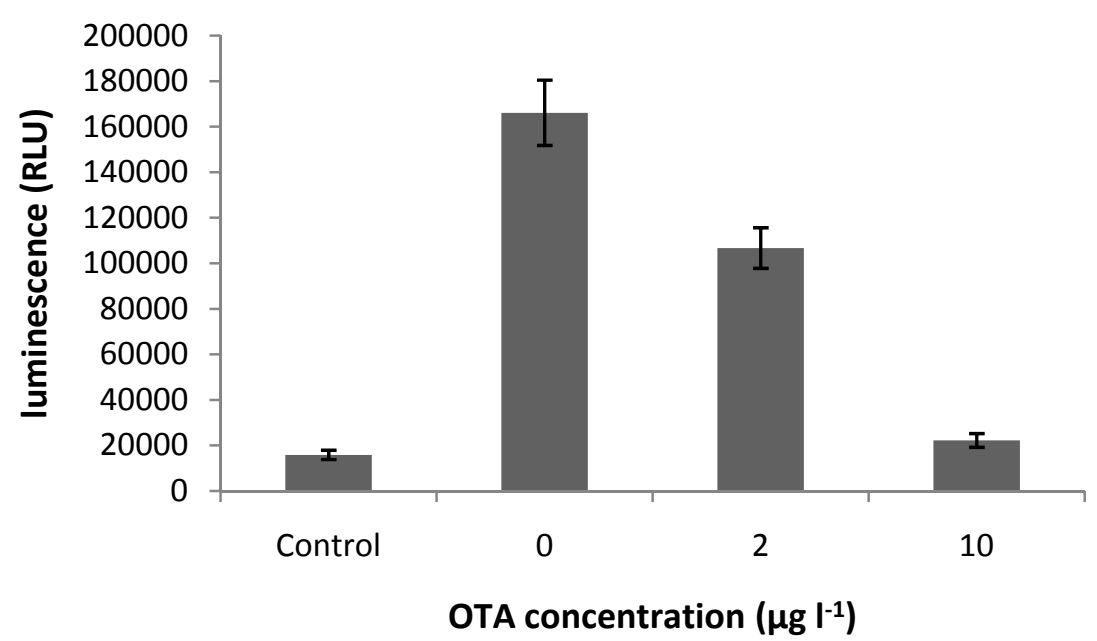

